повести Гоголя является, с одной стороны, отражения существующей мистической реальности, а с другой - желанием писателя подчеркнуть значимость и важность «мистической идеи» для самого себя и своих героев.

Список литературы:

1. Бабенко Л.Г. Лингвистический анализ художественного текста. Теория и практика: Практикум / Л.Г. Бабенко, Ю.В. Казарин. - 4-е изд., испр. - М.: Флинта: Наука, 2006. - 469 с.

2. Гоголь Н.В. Вечера на хуторе близ Диканьки. Миргород. -М.: Художественная литература, 1982. - 462с.

3. Даль В. Толковый словарь живого великорусского языка [Электронный pecypc]. - (Электрон.дан.). - Режим доступа: http://www. slovari.yandex.ru/ dict/dal/article/dal // - Загл. с экрана - Яз.рус.

4. Ожегов С.Ю., Шведова Н.В. Толковый словарь русского языка. - М.: Просвещение, 1992

5. Современный толковый словарь. / под ред. А.М. Прохорова [Электронный pecypc]. - Режим доступа: http://www.twirpx.com/file/1389507/

6. Современный толковый словарь русского языка Т.Ф. Ефремовой [Электронный pecypc]. - (Электрон.дан.). - Режим доступа: http://www. dic.academic.ru/contents.nsf/efremova //

7. Толковый словарь русского языка Д.Н. Ушакова [Электронный ресурс]. (Электрон.дан.). - Режим доступа: http://www.slovari.yandex.ru/ dict/ushakov //

\title{
Идейно-эстетическое своебразие романа Амма Аччыгыйа «Сааскы кэм»
}

\section{Сидорова С.P., студентка, Северо-Восточный федеральный университет, 2. Якутск E-mail: sandaarywka97@gmail.com}

\section{Научный руководитель: к.филол.н., доцент Герасимова Е.С.}

В якутском литературоведении творчество Н.Е. Мординова нередко воспринимали в идеологизированном ракурсе, а его метод трактовали как образец социалистического реализма. Но искусство писателя не укладывается в прокрустово ложе официального метода советской литературы. Амма Аччыгыйа не просто изобразил жизнь «в ее революционном развитии», а явился, согласно справедливому замечанию В.М. Переверзина, «выразителем духовных и социальных исканий народа саха в эпоху революционных изменений общества» [3, с.83]. «Народноцентричный» характер его эстетики в полной мере был реализован в романе «Весенняя пора», по праву ставшем «главной книгой литературы саха», своего рода «Книгой нации» [3, с. 84].

«Весенняя пора» - это произведение эпопейного плана с универсальным охватом жизненных явлений, с обстоятельным изображением человеческих характеров в их многообразных связях с общественным бытием. Автор романа глубоко раскрыл 
переломную эпоху в истории целого народа, первым в якутской литературе поставив и художественно разрешив национально-историческую проблематику.

Вообще в поэтике романа Н.Е. Мординова принципиальное значение имеют средства предметной изобразительности: портретистика, пейзаж, интерьер, художественная деталь. Как было уже отмечено, посредством описания внешности героя выражалось авторское отношение к нему. Вот портретная зарисовка Федора Веселова: «Он идет, вытянув тошую шею, будто принюхиваясь к чему-то. Кончик длинного горбатого носа и верхняя губа у него зелены от нюхательного табака, гноящиеся глаза пристально шарят по сторонам» [4, с. 138]. Совершенно по-другому выглядит портрет любимца детворы, батрака Егора Найына: «Невысокий, широкоплечий и, на удивление всем якутам, рыжеволосый и голубоглазый, он всегда был весел, хотя и сльл неудачником» [4, с. 237]. Нередко при описании внешнего вида или состояния своих героев писатель использовал анималистическую образность. Тот же Федор Веселов своим обликом внушает Никитке непонятное чувство, в котором сочетаются страх, жалость и брезгливость: «Костистая узкая спина, тонкая шея, тяжело качающаяся большая голова, белесое лицо - всем своим видом он напоминает ощъипанного и̧ьплленка» [4, с. 132]. Смех другого богатея Григория Егорова напоминал лошадиное «ржание». Могучий великан Василий Тохорон, «окруженный своей $и$ чужой детворой», «походил на большого вола среди телят» [4, с. 334].

В образотворчестве автор часто использовал аналогии с птицами. Так, у Федосьи шутливо спрашивают: «И чего mы, будто и не якутка вовсе: волосы - как ягель, нос - как у гагары? ?» [4, с. 339]. Она же, хватившись Никитку, сбежавшего к реке, «растрепанной птицей слетает вниз, к воде» и мечется по берегу, «подобно потерявшей детеныша оленихе» [4, с. 10]. Сам Никита Ляглярин во втором варианте романа сравнивается с «красным соколом». Проворная Майыс, ускользнув из рук Эрдэлира, «ласточкой полетела к своему дому» [4, с. 37]. Дети старшего и самого бедного из Егоровых, Михаила, высокого человека с безусым лицом, не ладившего со своими братьями, тоже были «крупные, похожие на отиа, напоминавщие утят перед взлетом» [4, с. 234]. А незадачливого Федора Ковшова бойкая, языкастая Евдешка сравнивает с «ощипанным петухом» [4, с. 370]. Образная анималистика использовалась автором не только в характерологических целях, но и для описания местности. Например: «Иван и Егордан выбрали себе лужайку копен на пять. Там, на месте высохшего озерка, трава была густая и слежалась, как шерсть на лбу быка» [4, с. 160]. Или еще: «Мокрая от грязи тропинка, то исчезая, то опять показываясь, черным червем извивалась между зыбкими болотныли кочками» [4, с. 214].

Художественный мир романа «Весенняя пора» при всей своей реальности и достоверности не лишен романтического начала. Оно присутствует в самой поэтике названия, которое предполагает идея возрождения и обновления природного и социального мира. Впрочем, подобный пафос был характерен для всей многонациональной советской литературы, о чем свидетельствовали созданные синхронно с «Весенней порой» романы татарского писателя К. Наджми «Весенние ветры» (1948) или бурятского художника слова Х. Намсараева «На утренней заре» (1950). Более того, известный специалист по этническим литературам США и Канады А. Ващенко усматривает типологические параллели между якутской литературой, в частности, романом Н. Мординова «Весенняя пора», и творчеством индейских писателей Д. Мэтьюза, Д. Макникла, С. Мамодэя [4]. 
В связи с этим особую значимость у Н. Е. Мординова приобретают образы природы и, в частности, проходящий через весь роман мотив реки, который становится развернутой поэтической метафорой судьбы его героя, начиная с первой главы, когда маленький Никитка чуть было не уплыл на утлой ветке, и кончая финалом, где могучий пароход уносит возмужавшего Никиту Ляглярина вдаль, и «щирокой, светлой дорогой к счастью лежит передним великая Лена-река» [4, с. 393]. То есть, индивидуальная «река» героя, «река» его души вливается в «реку» жизни народа. Подобная жизнеутверждающая философия жизни выражается в романе посредством природных образов: «Бесчисленные весенние ручейки, соединяясь становятся речкой. Речки образуют могучие, светлье реки, а реки питают бескрайнее море» [4, с. 335].

Однако и тут можно говорить о типологических процессах, так как в мировой литературе уже были подобные прецеденты. Роман великого французского писателя Р. Роллана «Жан-Кристоф» (1903-1912) открывается описанием величавого Рейна, на берегах которого родился герой, и хотя вся его остальная жизнь проходит на берегах другой реки - Сены, в конце ему грезится шум рейнских волн. Образ полноводной реки в ее неустанном движении символически воплощает характер героя, раскрывающийся в динамике, как поток, устремленный вперед. По своей композиции «Жан-Кристоф» принадлежал к жанру романа-потока, характерного для реалистической литературы XX века. Произведение Н.Е. Мординова тоже имеет признаки подобной жанровой формы.

Посредством зримых, осязаемых картин передается в романе восприятие Никиткой знаменитых некрасовских строк, прочитанных им при зыбком свете свечи под портретом русского поэта, который каким-то образом оказался в юрте старого Боллорутты: «Сейте разумное, доброе, вечное!» Горячее дыхание поэзии коснулось его детского сердца, от этого «слегка закружилась голова, радостно забилось сердие», и в повествование явственно вторгается авторский голос: «Так бывает, когда идешь в зимнюю стужу, замерзиий и голодный, по незнакомой лесной тропке - и вдруг неожиданно возникает перед тобой приветливый сноп искр из трубы теплого жилья, одиноко стоящего на опушке. Так бывало в раннем детстве осенним темным вечером. Ты давно уже сидишь один в юрте и тихо плачешь, потом, утомленный, начинаешь засыпать, прислонивиись к столу. И вот неожиданно открывается дверь, и ласковый голос матери зовет тебя» [4, с. 182].

Состояние природного мира, а также антитеза «дом - чужбина» способствуют раскрытию переживаний Никиты, когда они с матерью отправляются в улусный центр за подмогой. Покидая родные места, они попали под холодный дождь, сильно промокли и продрогли. На их счастье попался попутчик в лице Афанаса Матвеева, который обогрел и накормил их. В улусе им тоже была уготована весьма прохладная встреча. Зато обратно они возвращались, окрыленные вестью о победе красных в Якутске, и, казалось, сама природа радовалась вместе с ними. Федосья с сыном пошли другой, более дальней дорогой, чтобы быстрее увидеть красавицу Талбу и посетить родной Дулгалах: «По мере приближения к родной реке само небо будто прояснилось, чище становился воздух, ровнее дорога. У Никиты сладостно защемило сердие. Он был похож сейчас на молодого зверька, у него подергивались ноздри, горели глаза» [4, с. 299]. Он первым принес в наслег благую весть о победе Советской власти. В этом эпизоде тоже не обошлось без авторского отступления: «Радость возвращения в родные края может понять только тот, кто хоть раз покидал их. Счастье иенишь, лишь упустив его, здоровье - когда заболеешь, молодость - состарившись, друга поссоривиись с ним» [4, с. 298]. 
Важнейшим фактором, определяющим этногенетическую сущность любой национальной литературы, служит фольклорность, которая в наиболее чистом виде содержит в себе элементы и структуру душевного типа нации, своеобразия ее мышления, то есть менталитет. В романе Н. Е. Мординова наиболее ярким выражением художественной этнотрадиции является целая система пословиц и поговорок. Прежде всего они выполняют функцию эпиграфов, которые очень точно раскрывают внутренний смысл отдельных частей произведения. Например, вторая часть «Тропа испытаний» («Эрэйдээх ыллыгынан») снабжена эпиграфом «ИнчэБэй тирбэБэ быстыбат» (досл. «Сыромятный ремень не рвется»). В ней речь идет о том, как семья Лягляриных выдерживает все удары судьбы, Никита начинает учиться, а цвет народа саха не подвергается военному призыву. Или последней, пятой части романа предпослан эпиграф «Уол оқону дьоло түөрт өттүттэн көһүтэр» (досл. «Доброго молодца счастье ждет со всех четырех сторон»). В ней Никита находит свою жизненную стезю - становится учителем, затем поступает в Якутское педагогическое училище и, наконец, выходит на «широкую дорогу» - едет учиться в Москву. Поговорками и пословицами насыщен текст всего произведения. Некоторые из них имеют русские эквиваленты, например:

- Kыльый да тарбан, кылһн да көрдөс (Позудилось - почешись, полюбилось попросись);

- Суор хара5ын суор онпот (Ворон ворону глаз не выклюет);

- Camblblны биэс эрэй mohyйар, аттаахтан биир эрэй куотар (Пешего пять бед дожидаются, а от конного и одна бежит);

- Ac өhө cyox (Пища вражды не знает). Но большинство носит оригинальный характер:

- Оонньообутун хаһан эрэ о5ус буолан тахсыа (Игра с огнем до добра не доводит);

- Үгүстэн үгус охтуо, ауыйахтан аБыйах охтуо (От многих много падет, от немногих мало падет);

- Саһьлл - түүтүнэн, киһи - баайынан (Лисиц сравнивают по меху, а людей по богатству);

- Сүгэ түһүөр диэри дүлүн сынньанар (Пока топор опускается, бревно отдыхает). Фольклорная стихия в свою очередь придает повествованию романтический пафос. Слушая сказки, легенды, загадки бабушки Дарьи, маленький Никитка переносится из убогой юрты в совершенно иной мир: «Разве эти стены поблескивают толстыми полосками инея? Нет! Это серебряные украшения сказочного дворйа. Разве на полу мусор? Да нет же! Это стружски золотые раскиданы...» [4, с. 27].

Итак, идейно-эстетическое своеобразие романа Н.Е. Мординова проявилось в стремлении передать жизнь в широком контексте, в правдивом описании труда, быта, традиционного уклада, в умении нарисовать сложные обстоятельства национального бытия, раскрыть внутренний мир героев, в точной передаче живой народной речи, широком использовании фольклора, богатом юморе. Реалистическому методу Амма Аччыгыйа свойственна искренность, доверительность и убедительность тона. Создание художественных образов и картин сочетается с проблемностью и остротой мысли в исторических и массовых сценах, тонким психологическим анализом, словесным мастерством. 